c. 2

\title{
Distribution of Ord's Kangaroo Rats in Southeastern Alberta
}

\section{Fish \&: Wildilie Division}

WILDUFE CONSERVAION AND BIODIVERSIT SECTION

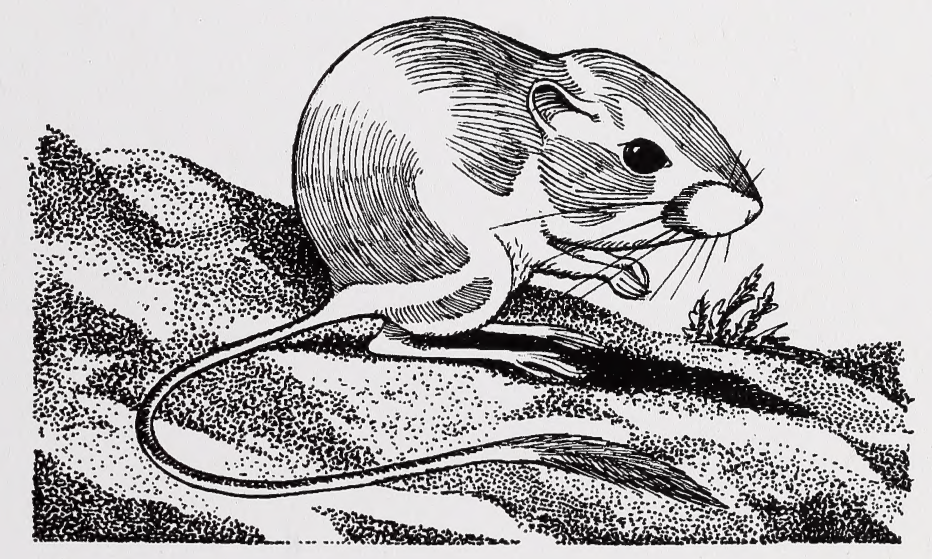

Alberta Species at Risk Report No. 63 
Digitized by the Internet Archive in 2016 


\title{
Distribution of Ord's Kangaroo Rats in Southeastern Alberta
}

\author{
David L. Gummer \\ Sandi E. Robertson
}

Alberta Species at Risk Report No. 63

January 2003

Project Partners: 
Publication No. I/096

ISBN: 0-7785-2343-8 (Printed Edition)

ISBN: 0-7785-2344-6 (On-line Edition)

ISSN: 1496-7219 (Printed Edition)

ISSN: 1496-7146 (On-line Edition)

Illustration: Brian Huffman

For copies of this report, contact:

Information Centre - Publications

Alberta Environment / Alberta Sustainable Resource Development

Main Floor, Great West Life Building

9920108 Street

Edmonton, Alberta T5K 2M4

Telephone: (780) 422-2079

\section{OR}

Information Service

Alberta Environment / Alberta Sustainable Resource Development \#100, 311512 Street NE

Calgary, Alberta T2E 7J2

Telephone: (403) 297-3362

\section{OR}

Visit our website at:

http://www3.gov.ab.ca/srd/fw/riskspecies/

This publication may be cited as:

Gummer D. L. and S. E. Robertson. 2003. Distribution of Ord's kangaroo rats in southeastern Alberta. Alberta Sustainable Resource Development, Fish and Wildlife Division, Alberta Species at Risk Report No. 63. Edmonton, AB. 
TABLE OF CONTENTS

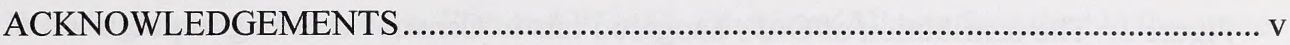

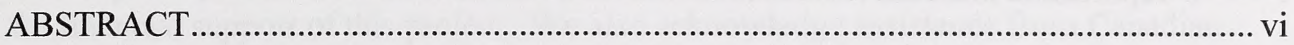

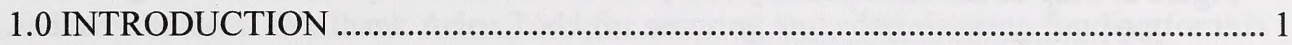

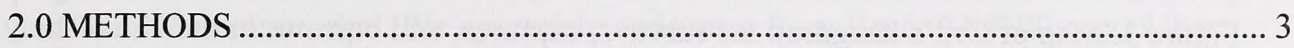

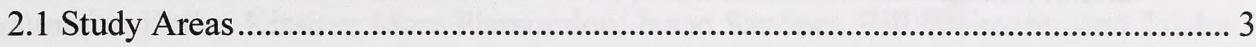

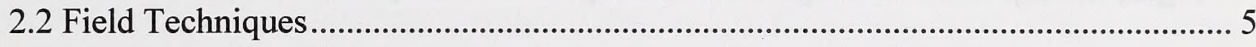

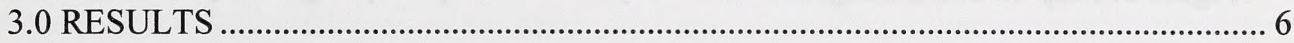

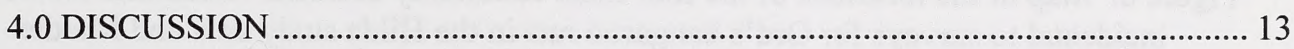

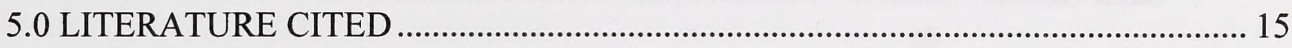




\section{LIST OF FIGURES}

Figure 1. The distribution of Ord's kangaroo rats in Canada according to published reports and museum records

Figure 2. Map of the three primary study areas for our surveys for Ord's kangaroo rats in 2001 4

Figure 3. Map of Ord's kangaroo rat surveys, captures, and burrows in the Hilda study area...... 8

Figure 4. Map of Ord's kangaroo rat surveys in the Manyberries study area. 9

Figure 5. Map of Ord's kangaroo rat surveys in the Purple Springs study area. 10

Figure 6. Map of the locations of the four most commonly detected vertebrates recorded incidental to surveys for Ord's kangaroo rats in the Hilda study area and Middle Sand Hills.

Figure 7. Map of the locations of olive-backed pocket mice recorded incidental to surveys for Ord's kangaroo rats in the Manyberries study area

\section{LIST OF TABLES}

Table 1. Sampling effort and numbers of Ord's kangaroo rat captures and burrows that were recorded during surveys for kangaroo rats during 2001. 


\section{ACKNOWLEDGEMENTS}

We are grateful to the Alberta Fish and Wildlife Division (Alberta Sustainable Resource Development) and the Provincial Museum of Alberta (Alberta Community Development) for financial support of this project. We also acknowledge assistance from Canadian Forces Base Suffield, EnCana Suffield Gas Pipelines Inc., and many private landowners and leaseholders. We thank Arlen Todd for securing and administering funding for this project from the Alberta Fish and Wildlife Division and for his comments on an earlier version of the manuscript. We appreciate assistance from Bruce McGillivray, Albert Finnamore, and Colleen Steinhilber. We thank Jim Burns for editing the report and Yan Coulombe, Kelley Kissner, Marc Plamondon, Jason Sanders, Bill Weimann, and Trisha Westers for their valuable field assistance. 


\begin{abstract}
Ord's kangaroo rat (Dipodomys ordii) occurrence in Alberta is well documented for the Middle Sand Hills; however, there was sufficient uncertainty regarding this endangered species' distribution in the province to warrant specialized surveys in other sand hill areas. We conducted surveys for kangaroo rats during 2001 in the vicinities of Hilda, Manyberries, and Purple Springs because each of these areas appeared to have the sandy soils and sand hill landforms that kangaroo rats require. Discovery of kangaroo rat populations in any of these areas would be significant because it could potentially reduce or refute the apparent geographic isolation of the northern population. Surveys consisted of searching at night for kangaroo rats, their conspicuous tracks, and burrows, on foot with bright flashlights and from a 4WD vehicle with spotlights. From May through August 2001 we conducted 88 nights of field surveys, during which we searched 31 subjectively selected sites and 95 random transects for kangaroo rat presence. We discovered one small population of kangaroo rats in a new vicinity near the Middle Sand Hills, on the south side of the South Saskatchewan River in Townships 20 and 21, Range 1, W4 (approximately $16 \mathrm{~km}$ north of the Hilda sand hills). Kangaroo rats were not discovered inhabiting any other locales that were previously undocumented. We consider the likelihood that Hilda, Manyberries, and Purple Springs sand hills harbour undetected populations of kangaroo rats is negligible. Although we discovered one small population on the south side of the South Saskatchewan River, our surveys reaffirmed that kangaroo rats have a limited geographic distribution in Alberta and are presumably genetically isolated from more southern conspecifics.
\end{abstract}




\subsection{INTRODUCTION}

Conservation and management of rare and endangered species rely on accurate and detailed knowledge of the species' geographic distributions. Ord's kangaroo rats (Dipodomys ordii; henceforth 'kangaroo rats') are found in the Great Plains of western and central North America, from central Mexico to southern Canada (Hall 1981, Schmidly et al. 1993). The species occurs in Alberta in a small geographic area at the northernmost periphery of its range (Fig. 1; Gummer 1995, Gummer 1997a, Gummer 1997b, Gummer and Barclay 1997, Gummer and Gummer 1997). Long-term geographic isolation at relatively high latitude appears to have caused northern kangaroo rats to adopt distinct characteristics (e.g., hibernation, rapid sexual maturity; Gummer 1997a, Gummer and Barclay 1997) that are likely to be endemic to Alberta and Saskatchewan. The Alberta population crashes during most winters, with the early spring breeding population reaching a minimum of less than 1000 individuals (Gummer 1997a, Gummer 1997b, Gummer and Barclay 1997). As a result, any natural or human disturbances that directly or indirectly increase mortalities of kangaroo rats have the potential to rapidly extirpate local populations, leaving the Alberta population close to extinction (Gummer and Robertson 2002). Consequently, the Alberta Endangered Species Conservation Committee (2000) recommended that kangaroo rats be listed as "endangered" in the province according to the criteria of the World Conservation Union (IUCN 1994). Nationally, kangaroo rats are a species of "special concern" due to the inherent risks associated with occurrence in Canada in a very small geographic area at the periphery of the species range (Gummer 1995, Committee On the Status of Endangered Wildlife In Canada 2000).

Kangaroo rats are bipedal mammals that hop on their large hind limbs. In Alberta, the mean body mass and measurements of the species are $59 \mathrm{~g}$ and $250-138-42-13 \mathrm{~mm}$, respectively (Provincial Museum of Alberta unpubl. data). Kangaroo rats are highly adapted for desert survival: they are renowned for their ability to conserve water in extremely hot and dry environments (French 1993). They are nocturnal and fossorial, spending the majority of time in their underground nests and tunnels. Because they dig extensive burrow systems and rely on their hopping-style of locomotion to escape from predators, kangaroo rats prefer sparsely vegetated, sandy-soiled habitats such as sand dunes and other steep sandy slopes (Nero 1956, Nero and Fyfe 1956, Baron 1979, Kenny 1989). The species is also known to opportunistically inhabit sandy-soiled, disturbed areas such as sandy trails, fireguards, and gravel roads in sand hill areas (Smith and Hampson 1969, Reynolds and Armbruster 1971, Smith 1972, Gummer 1995, Gummer 1997a, Gummer 1997b, Gummer and Barclay 1997, Gummer and Gummer 1997, Reynolds et al. 1999).

Kangaroo rat occurrence in Alberta appears to be limited to the vicinity of the Middle Sand Hills, which includes the eastern portion of Canadian Forces Base Suffield and adjacent areas between the South Saskatchewan and Red Deer rivers (Fig. 1; Smith and Hampson 1969, Smith 1972, Reynolds and Armbruster 1971, Gummer 1995, Gummer 1997a, Gummer 1997b, Gummer and Barclay 1997, Gummer and Gummer 1997, Reynolds et al. 1999). However, the life history and behaviour of kangaroo rats are such 


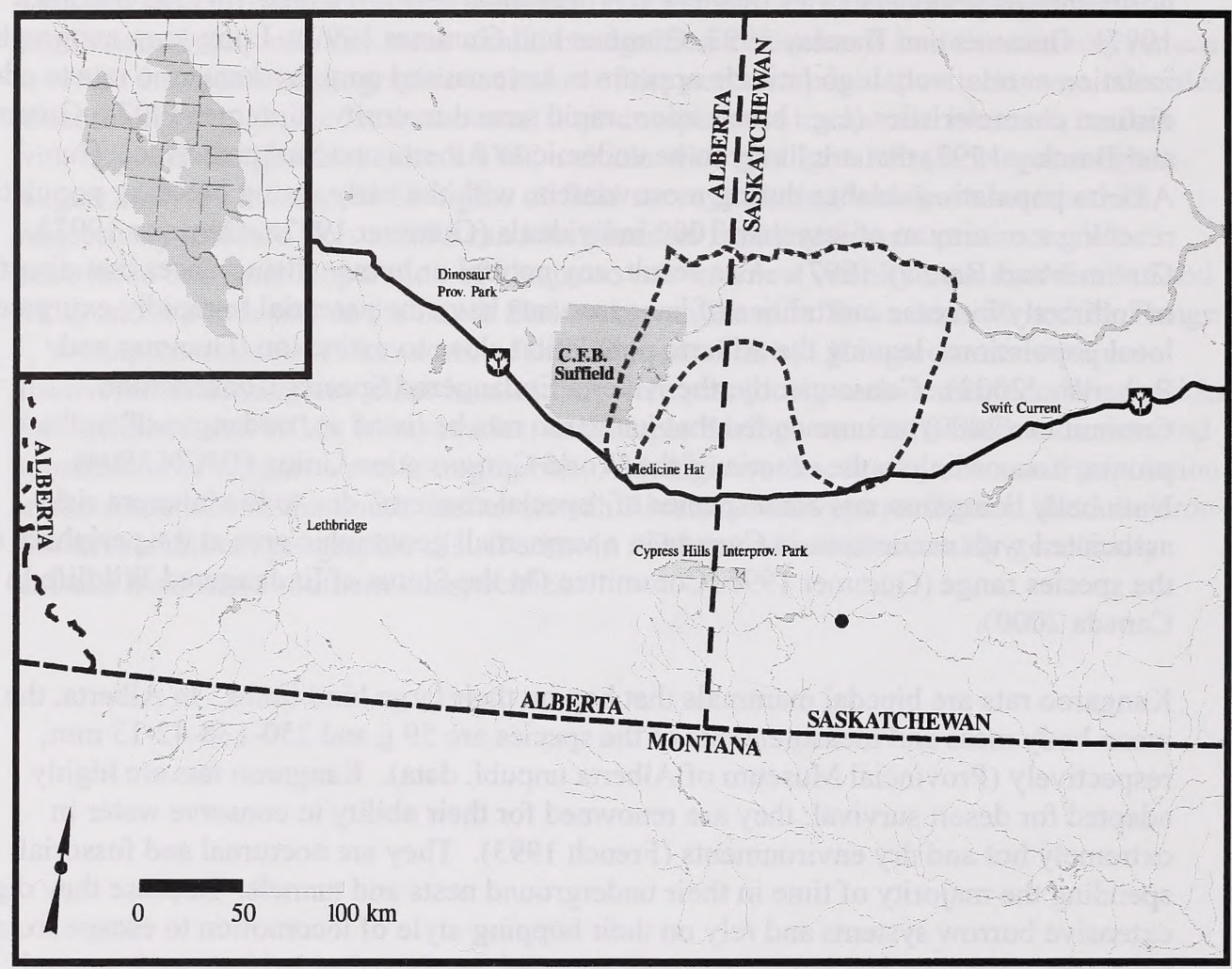

Figure 1. The distribution of Ord's kangaroo rats in Canada (encompassed by dashed border) according to published reports and museum records (Gummer and Barclay 1997). One anecdotal record near Ravenscrag, Saskatchewan ( $\bullet$; Carleton 1956), did not follow the species' affinity for sand hills and may have been accidental or erroneous. The North American distribution of the species is shown in the inset (Hall 1981, Schmidly et al. 1993). 
that they are unlikely to be detected by general multi-species survey techniques: kangaroo rats are small, nocturnal, short-lived, and difficult to detect by standard survey and trapping techniques (e.g., Reynolds et al. 1999). Other sparsely vegetated sand hill areas are known to exist in Alberta, south of the Middle Sand Hills, yet there are no documented records of kangaroo rats in those locales (Gummer and Gummer 1997). As a result, specialized surveys for kangaroo rats were conducted in those areas during 1997 (Gummer and Gummer 1997). While these surveys did not detect any previously undocumented populations, the sand hills near the towns of Hilda, Manyberries, and Purple Springs were identified as key areas that required more intensive surveys (Gummer and Gummer 1997).

There are also ambiguous records of kangaroo rat specimens that were collected by the Provincial Museum of Alberta in the "Hilda-Empress area" during 1970 (Accession Nos. Z70.53.72 and Z70.53.73) and by the U.S. Biological Service near "Medicine Hat" (Anderson 1946). Precise coordinates were not recorded for any of these aforementioned specimens. It is unclear from which side of the South Saskatchewan River these Alberta specimens were collected. Discovery of kangaroo rats in any of these areas would be significant because it could potentially reduce or refute the apparent geographic isolation of the northern population.

There was sufficient uncertainty regarding this endangered species' distribution in Alberta to warrant more intensive, specialized surveys for the species. Hence, we conducted surveys for kangaroo rats in the vicinities of Hilda, Manyberries, and Purple Springs during 2001.

\subsection{METHODS}

\subsection{Study Areas}

We conducted specialized surveys from May through August 2001 near the towns of Hilda, Manyberries, and Purple Springs in southeastern Alberta (Fig. 2). Each of these areas contains sand hill habitats that appear to represent suitable habitat for kangaroo rats. We also conducted surveys and recorded kangaroo rat records within the species' known geographic range (Middle Sand Hills; Fig 2.), incidental to training of field staff, travel between study sites, and a concurrent research project (Gummer and Robertson 2002). All of the study areas occur in the dry mixedgrass natural subregion and within the generally accepted geographic range of Ord's kangaroo rats (Hall 1981, Schmidly et al. 1993).

The predominant land use in the sand hills is cattle grazing, although we also surveyed some sites that were cropland and hayland. All of the study areas have been subjected to intensive oil and gas exploration and extraction activities. Within the Middle Sand Hills, the eastern portion of Canadian Forces Base Suffield is proposed for National Wildlife Area status. There is no public access to the proposed National Wildlife Area nor is there 


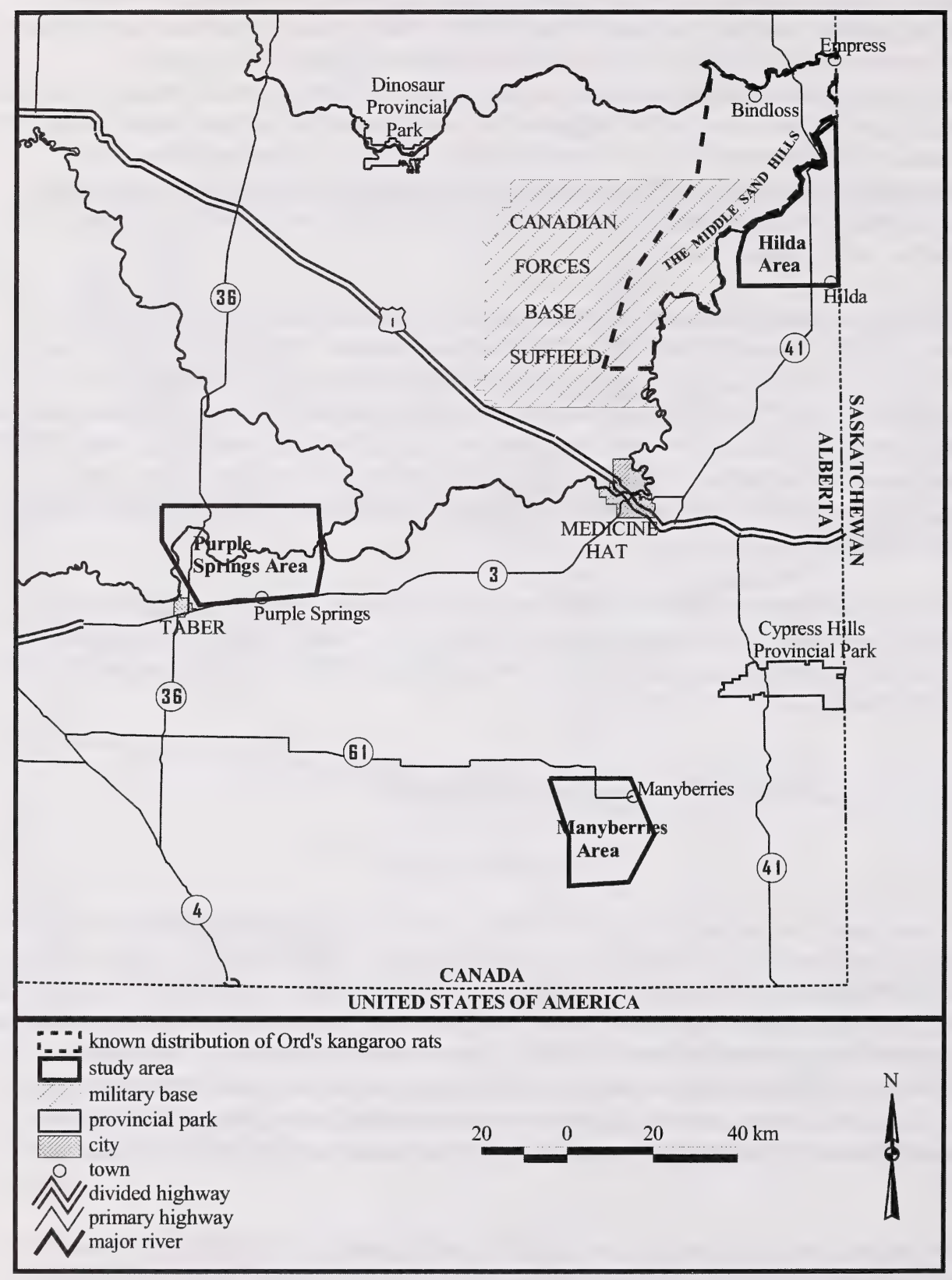

Figure 2. Map of the three primary study areas for our surveys for Ord's kangaroo rats in 2001. The known distribution of the species in the Middle Sand Hills is also shown for reference. 
any direct use of the landscape for military training; it is used strictly as a safety (in the event of ricochet) buffer for military training.

\section{$\underline{2.2 \text { Field Techniques }}$}

We conducted field surveys for kangaroo rats during periods when the odds of detection were highest. Kangaroo rats are nocturnal and reduce their aboveground activity in response to ambient nighttime light conditions (Kaufman and Kaufman 1982) and therefore we conducted surveys: during the new moon period, when the moon was below the horizon, and when there was dark cloud cover. Kangaroo rats are also sensitive to inclement weather (Kenny 1989); we avoided sampling during strong winds or heavy rain. Surveys were conducted during the summer months when kangaroo rats are actively foraging aboveground and populations are typically high and conspicuous (Gummer 1995, Gummer 1997a, Gummer and Gummer 1997).

Daytime reconnaissance surveys were conducted to become familiar with the study areas, establish landowner contacts, and subjectively search for sand dunes, blowouts, and other potential habitats. We examined subjectively selected sites in the daylight on foot for characteristic kangaroo rat footprints, tail drags, burrows, and runways. Search effort was focussed on the interface of vegetation and bare sand where individual kangaroo rats would have been expected to travel during the preceding night.

In addition to subjectively selected sites, random transect locations were taken from a stratified random sample generated by a geographic information system (Idrisi32, Clark Labs, Worcester MA) for each of the primary study areas. Random transects were surveyed at night by two personnel walking in parallel, 10 metres apart, searching with bright flashlights for a distance of 250 metres in a random direction from the start point. We recorded all observations of kangaroo rats, footprints, tail drags, or burrows. Two personnel effectively searched transects that were 20 metres in width ( 5 metres on either side of each observer).

Nighttime follow-up surveys of subjectively selected habitats were conducted by vehicle and on foot. Vehicle surveys involved driving slowly $\left(30 \mathrm{~km} \mathrm{~h}^{-1}\right)$ with the headlights on and using spotlights (Brinkmann, $10^{6}$ candle power) to scan the edges of vegetation along roads, trails, and firebreaks for kangaroo rats ("nightlighting"; Gummer et al. 1997, Carnegie et al. 2001). We estimate that vehicle surveys effectively searched transects that were 20 metres in width. Potential habitats that could not be surveyed by vehicle were examined on foot using bright flashlights to search for kangaroo rats, footprints, tail drags, and burrows. We revisited some locations on more than one night if the habitat appeared favourable for kangaroo rat occurrence.

Observations were georeferenced to the nearest 10 metres in Universal Transverse Mercator (UTM) coordinates (zone 12, World Geodetic System 1984) using a hand-held Global Positioning System (GPS; Garmin 12CX, Olathe KS). When kangaroo rats were observed, they were pursued on foot and caught by hand. Individual kangaroo rats were 
marked with one numbered eartag and a subcutaneous microchip (Avid Canada, Calgary, AB). Sex, age, mass, reproductive status, presence/absence of ectoparasites, eartag, and microchip identifier were recorded for each kangaroo rat that was captured. We also recorded observations of other vertebrates that were observed incidentally during surveys for kangaroo rats. All of the data were subsequently entered into Microsoft Access relational database management system at the Provincial Museum of Alberta and submitted digitally to the Alberta Fish and Wildlife Division for import into the Biodiversity Species Observation Database.

\subsection{RESULTS}

Overall, we conducted surveys for kangaroo rats on 21 days and 88 nights between 21 May and 31 August 2001. We surveyed a total of $913 \mathrm{~km}$ of potential habitats, including 31 subjectively selected sites and 95 random transects (Table 1). We recorded 788 georeferenced kangaroo rat records in the Middle Sand Hills, incidental to training, travel between study sites, and cooperation with staff on a concurrent research project.

We discovered a previously undocumented population of kangaroo rats during vehicle nightlighting surveys in the northeast portion of the Hilda study area (Townships 20 and 21 , Range 1, W4), approximately $16 \mathrm{~km}$ north of the Hilda sand hills. The kangaroo rats were found inhabiting fallow cropland and adjacent sandy banks along a gravel road. There, we enumerated 11 individual kangaroo rats and recorded 90 kangaroo rat burrows in the fields and roadside (Fig. 3). Otherwise, we found no evidence of kangaroo rats anywhere else in the Hilda area, despite the abundance of sand hills therein.

The Manyberries and Purple Springs study areas both contained sand hills and numerous open, eroding sandy areas that appeared to represent appropriate kangaroo rat habitat. However, we found no evidence whatsoever of kangaroo rats occurring in either of these study areas (Figs. 4 and 5).

We acquired 788 incidental kangaroo rat records in the Middle Sand Hills. Kangaroo rats were observed directly on 531 occasions, including 390 captures of 180 different individuals (Fig. 3) and 141 occasions when the kangaroo rat was observed but not caught. We also recorded the locations of 257 confirmed kangaroo rat burrows in the Middle Sand Hills.

During field surveys we opportunistically recorded 602 incidental observations of other vertebrates, including many that are perceived as rare or species-at-risk. The olivebacked pocket mouse (Perognathus fasciatus) was the most commonly detected small mammal ( $n=70$; Figs. 6 and 7). Other rare or at-risk species that were observed coincident to surveys for kangaroo rats included the northern grasshopper mouse (Onychomys leucogaster, $\mathrm{n}=5$; Fig. 6), burrowing owl (Athene cunicularia, $\mathrm{n}=3$ ), common poorwill (Phalaenoptilus nuttallii, $\mathrm{n}=1$ ), prairie falcon (Falco mexicanus, $\mathrm{n}=$ 1), short-eared owl (Asio flammeus, $\mathrm{n}=2$ ), bull snake (Pituophis catenifer, $\mathrm{n}=3$ ), prairie 
Table 1. Sampling effort and numbers of Ord's kangaroo rat captures and burrows that were recorded during surveys for kangaroo rats in three priority study areas (Hilda, Manyberries, and Purple Springs) and their known range (Middle Sand Hills) during 2001.

\begin{tabular}{|c|c|c|c|c|c|c|c|c|}
\hline Study area & $\begin{array}{r}\text { Total area } \\
\left(\mathrm{km}^{2}\right)\end{array}$ & Days $^{2}$ & Nights $^{3}$ & $\begin{array}{r}\text { Distance } \\
(\mathrm{km}) \\
\end{array}$ & $\begin{array}{c}\text { Selected } \\
\text { sites }^{5}\end{array}$ & $\begin{array}{l}\text { Random } \\
\text { transects }^{6}\end{array}$ & Captures $^{7}$ & Burrows $^{8}$ \\
\hline Hilda & 500 & 12 & 22 & 360 & 15 & 46 & 11 & 90 \\
\hline Manyberries & 450 & 4 & 4 & 87 & 6 & 28 & 0 & 0 \\
\hline $\begin{array}{l}\text { Purple } \\
\text { Springs }\end{array}$ & 700 & 5 & 5 & 306 & 10 & 21 & 0 & 0 \\
\hline $\begin{array}{l}\text { Middle } \\
\text { Sand Hills }\end{array}$ & 240 & 0 & 57 & 160 & 0 & 0 & 390 & 257 \\
\hline Total & 1890 & 21 & 88 & 913 & 31 & 95 & 401 & 347 \\
\hline $\begin{array}{l}\text { Approximate } \\
{ }^{2} \text { Number of da } \\
\text { Number of da } \\
{ }^{4} \text { Total distance } \\
5 \text { Number of su } \\
\text { Number of ra } \\
\text { Number of ca } \\
{ }^{3} \text { Number of co }\end{array}$ & $\begin{array}{l}\text { xtent of surv } \\
\text { s on which } \\
\text { s on which } \\
\text { jectiveyed at } \\
\text { domly select } \\
\text { tures of kang } \\
\text { firmed kang. }\end{array}$ & $\begin{array}{l}\text { ys in eac } \\
\text { ytime r } \\
\text { ghttime } \\
\text { ast once, } \\
\text { ted sites } \\
\text { d transec } \\
\text { roo rats }\end{array}$ & $\begin{array}{l}\text { h study a } \\
\text { connaiss } \\
\text { surveys v } \\
\text { includin } \\
\text { that wer } \\
\text { ts that we } \\
\text { that were }\end{array}$ & $\begin{array}{l}\text { a. } \\
\text { re conducte } \\
\text { vehicle and } \\
\text { earched on } \\
\text { searched } \\
\text { ecorded dur }\end{array}$ & $\begin{array}{l}\text { veys were } \\
\text { d. } \\
\text { foot survey } \\
\text { foot. } \\
\text { n foot. } \\
\text { ing surveys } \\
\text { led during }\end{array}$ & $\begin{array}{l}\text { conducted. } \\
\text { ys. }\end{array}$ & & \\
\hline
\end{tabular}




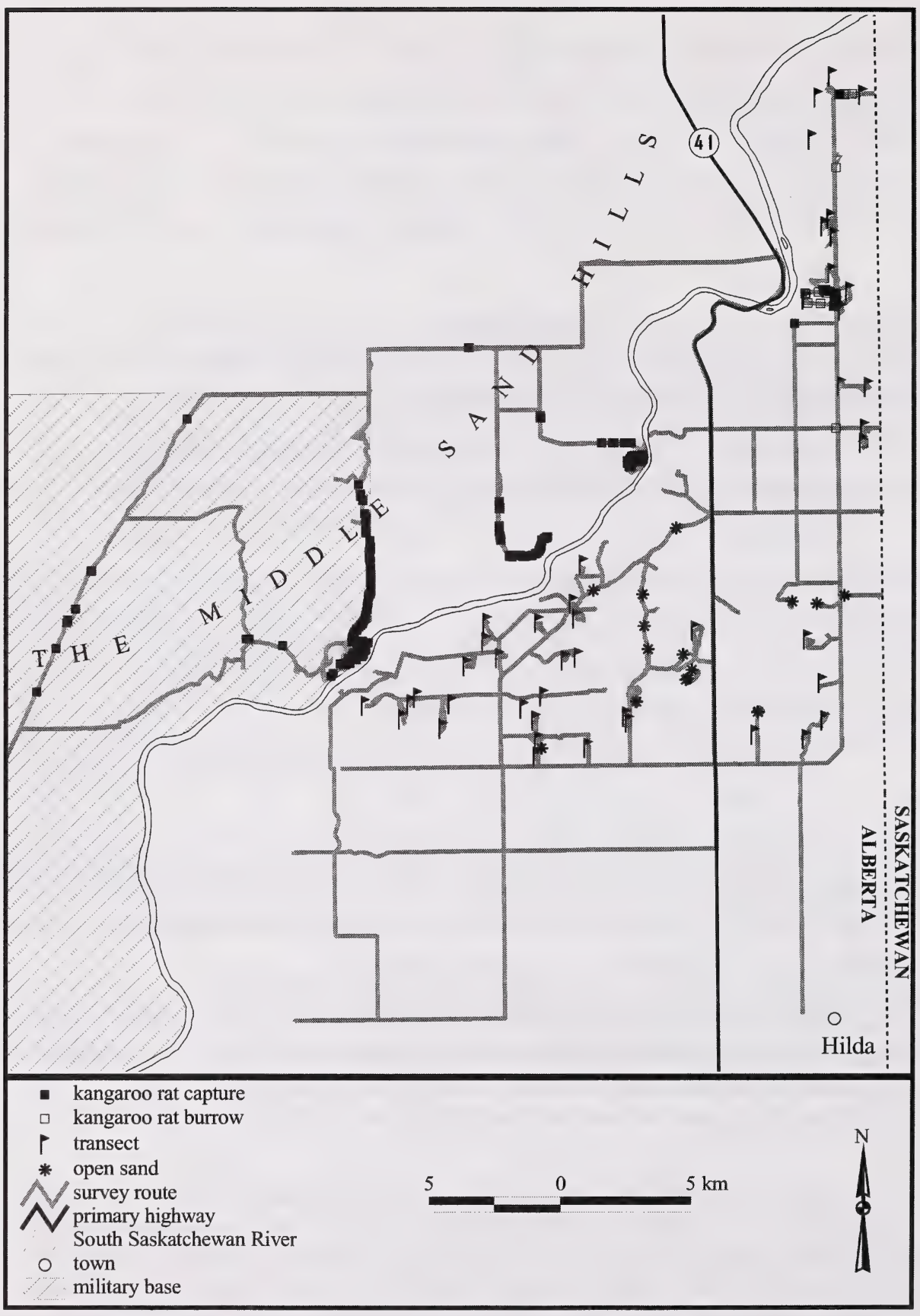

Figure 3. Map of Ord's kangaroo rat surveys, captures, and burrows in the Hilda study area. Survey routes and capture locations within the species' known range of the Middle Sand Hills are also shown for reference. 


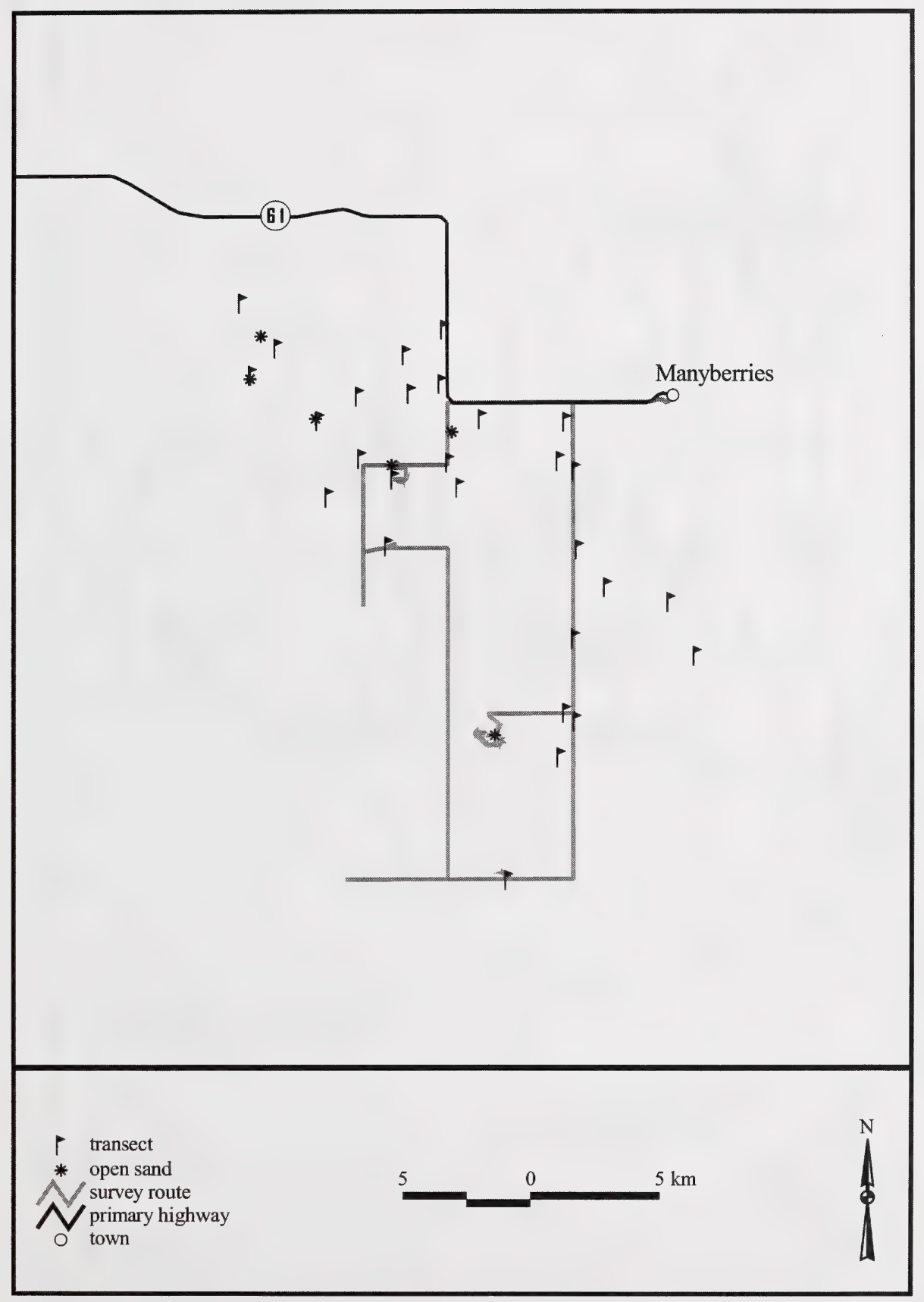

Figure 4. Map of Ord's kangaroo rat surveys in the Manyberries study area. 


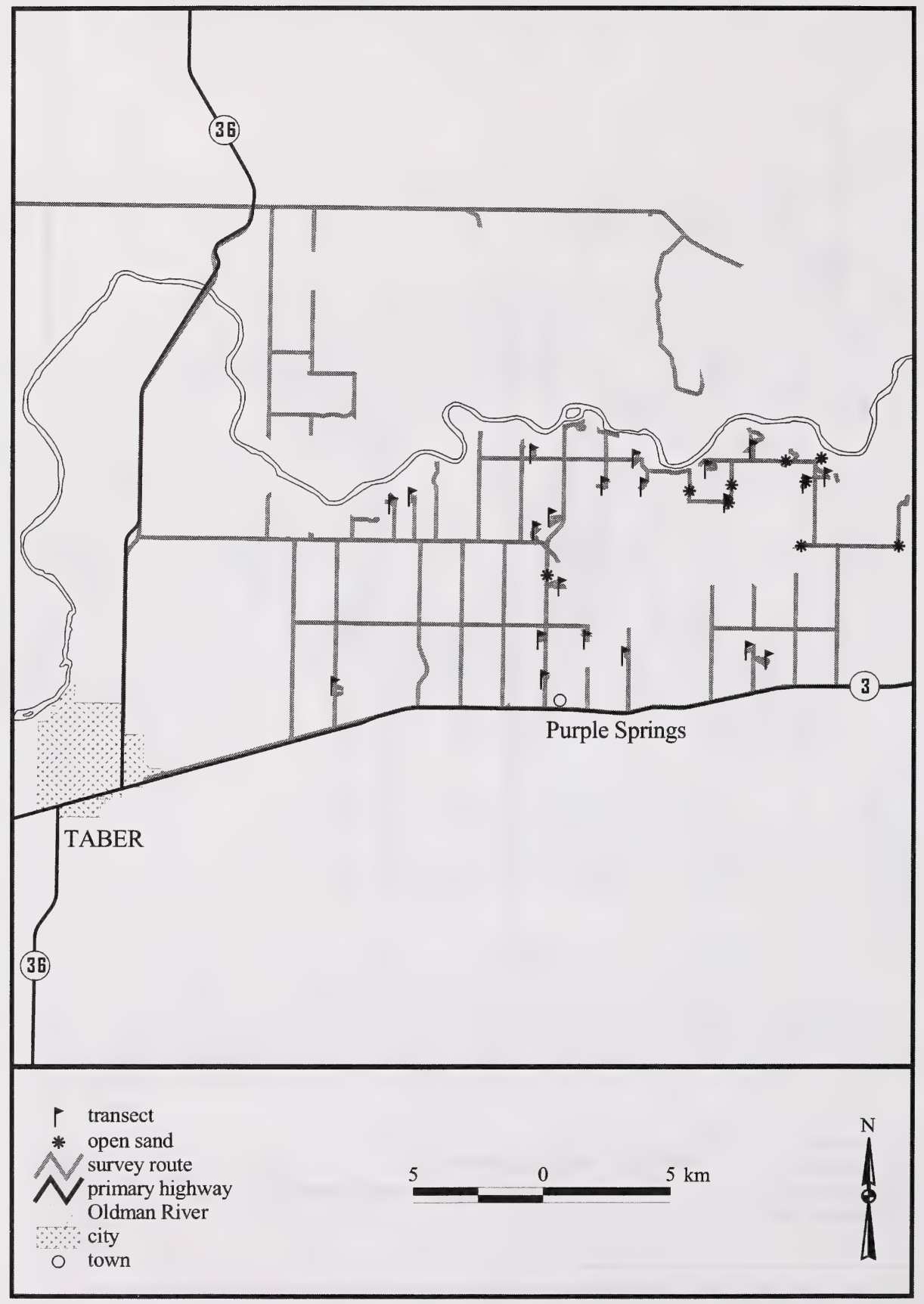

Figure 5. Map of Ord's kangaroo rat surveys in the Purple Springs study area. 


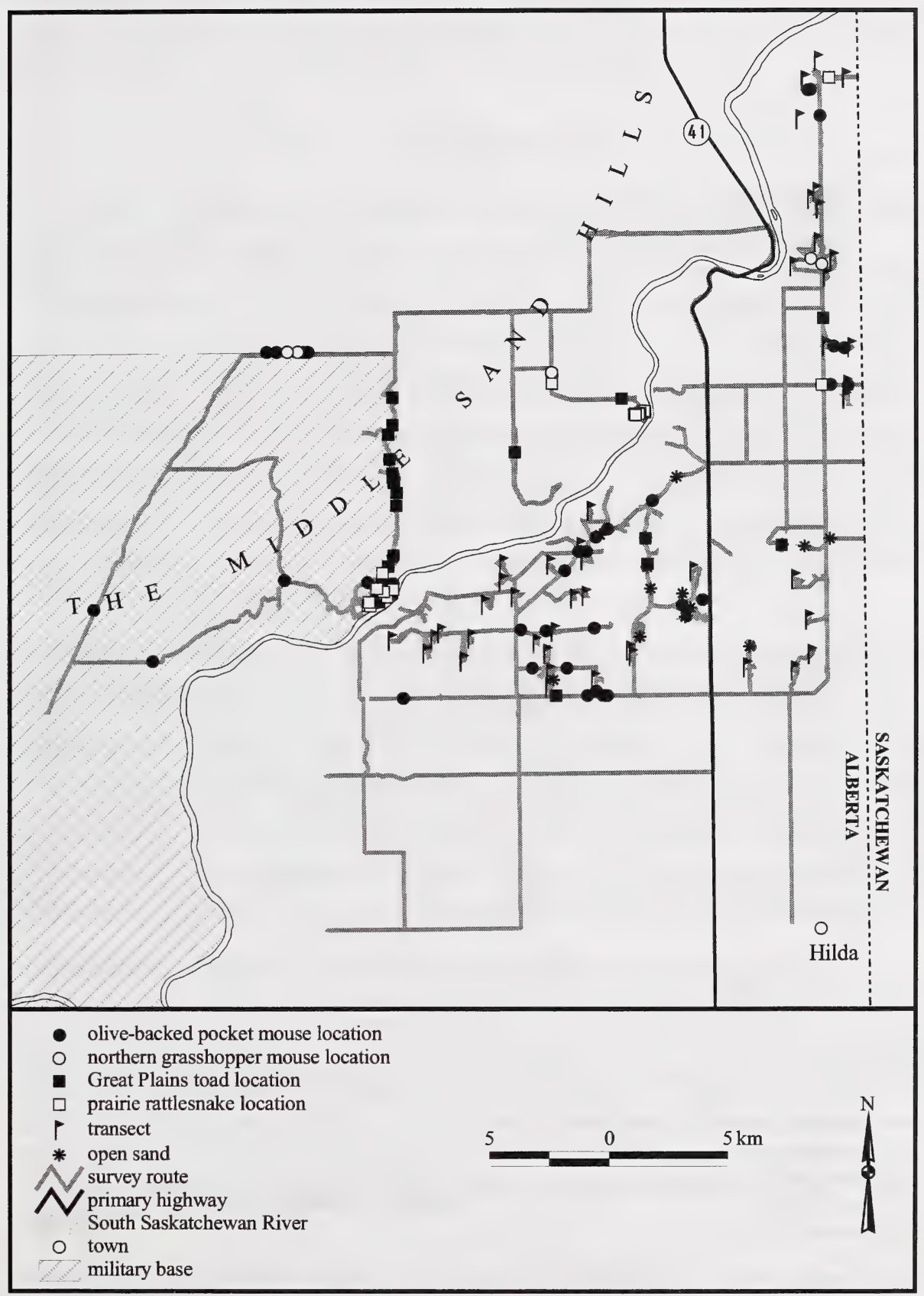

Figure 6. Map of the locations of the four most commonly detected vertebrates recorded incidental to surveys for Ord's kangaroo rats in the Hilda study area and Middle Sand Hills. Survey routes, transects, and open sand locations are also shown for reference. 


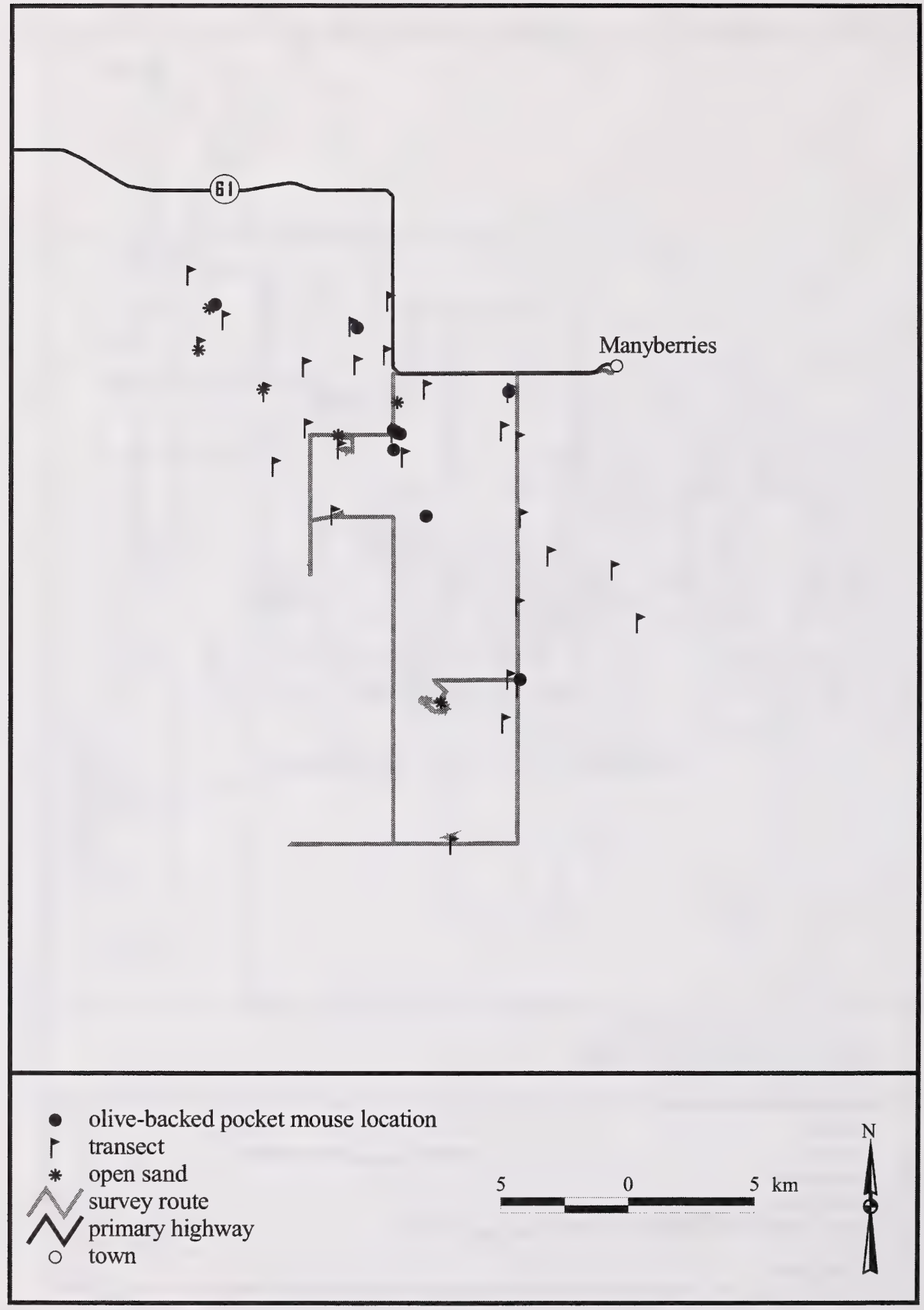

Figure 7. Map of the locations of olive-backed pocket mice recorded incidental to surveys for Ord's kangaroo rats in the Manyberries study area. Survey routes, transects, and open sand locations are also shown for reference. 
rattlesnake (Crotalus viridis, $\mathrm{n}=34$; Fig. 6), wandering garter snake (Thamnophis elegans, $\mathrm{n}=1$ ), Great Plains toad (Bufo cognatus, $\mathrm{n}=51$; Fig. 6), northern leopard frog (Rana pipiens, $\mathrm{n}=2$ ), and plains spadefoot (Spea bombifrons, $\mathrm{n}=2$ ).

\subsection{DISCUSSION}

Our surveys for kangaroo rats reaffirmed that kangaroo rats have a restricted geographic distribution in Alberta and that they are geographically isolated from southern conspecifics in adjacent Montana (Gummer 1995, Gummer 1997a, Gummer 1997b, Gummer and Barclay 1997, Gummer and Gummer 1997). We discovered one previously undocumented population of kangaroo rats on the south side of the South Saskatchewan River and we consider that the likelihood that the Hilda, Manyberries, and Purple Springs sand hills harbour additional populations of kangaroo rats is negligible. If we had discovered additional undocumented populations, particularly in the sand hills near Manyberries or Purple Springs, then considerable doubt would have been cast upon the premise of geographic isolation of Alberta kangaroo rats. However, the only newfound population that we detected was very close to previously known populations of kangaroo rats in Alberta and Saskatchewan and, therefore, Alberta kangaroo rats are most likely isolated from southern conspecifics.

The newly discovered kangaroo rat population represents the only documented location for this species on the south side of the South Saskatchewan River in Alberta. It is extremely close to the previously known locations in the Middle Sand Hills and in adjacent Saskatchewan. It will prove valuable for wildlife biologists and land managers to be aware of this population when making decisions regarding wildlife conservation and land management in the vicinity, as well as for future population monitoring and estimates of the overall Alberta kangaroo rat population. However, the actual geographic coordinates of this population are so close to the previously known population that they do not measurably reduce the apparent geographic isolation of Alberta kangaroo rats.

The newfound kangaroo rat population appeared to be small and localized. The population was located within two kilometres of the Saskatchewan border and we speculate that it may have resulted from recent immigration from nearby sand dunes in adjacent Saskatchewan (Baron 1979). The kangaroo rats occupied ephemeral habitat (fallow cropland) that is presumably cultivated frequently. Hence, it is possible that this particular Alberta subpopulation may represent a "sink" population: kangaroo rats may immigrate from Saskatchewan during years when conditions are favourable and recruitment is high, yet they are likely to suffer unsustainably high mortality in this particular habitat in Alberta.

We assume that the newly discovered kangaroo rat population is more closely linked to Saskatchewan kangaroo rats than to the Alberta population in the Middle Sand Hills. It is unlikely that there is significant connectivity between kangaroo rats on opposite sides of the South Saskatchewan River because kangaroo rats cannot swim and they remain 
underground in their burrows during cold winter periods when the river is ice-covered (Gummer 1997, Gummer and Barclay 1997).

We strongly urge that the Alberta population not be considered or managed as a "closed" population, despite the long distance isolation from southern conspecifics in Montana. Saskatchewan kangaroo rats and habitats should be considered in any large-scale population and habitat models or conservation and management strategies.

The sand hills near Manyberries and Purple Springs appear to represent appropriate habitat for kangaroo rats. However, we are confident that if kangaroo rats occurred in either vicinity during 2001, we would have detected at least one kangaroo rat or evidence of its occupation. It is unclear whether kangaroo rats ever occupied these sand hills, and if so, when the populations were extirpated. This question may eventually benefit from paleoecological studies; in Saskatchewan, kangaroo rat remains have been found in archaeological and paleoecological sites well beyond the species' current range in the province (E. Walker, pers. comm.).

Kangaroo rats' behaviours and life history are such that they are difficult to detect using standard multi-species survey and trapping techniques (e.g., Reynolds et al. 1999). Therefore we adopted the specialized survey techniques that had proven successful in known parts of the species geographic range (Gummer et al. 1997, Gummer and Gummer 1997). Given the escalating competition for wildlife conservation and research funding, many biologists are praising the merits and economy-of-effort of multi-species approaches. We caution that specialized surveys and techniques will always be critical to an accurate knowledge of populations of rare and endangered species. 


\subsection{LITERATURE CITED}

Alberta Endangered Species Conservation Committee. 2000. First report of the Alberta Endangered Species Conservation Committee. Alberta Environment. Edmonton.

Anderson, R. M. 1946. Catalogue of Canadian recent mammals. National Museum of Canada, Bull. No. 102, Biological. Series 31.

Baron, D. 1979. Evidence of Kangaroo Rats near Burstall, Saskatchewan. Blue Jay. 37: 240.

Carleton, R. R. 1956. Kangaroo rat. Blue Jay. 14: 100.

Carnegie, S. D., E. J. Urton, and D. L. Gummer. 2001. Short-eared owl, Asio flammeus, attack on a burrowing owl, Athene cunicularia, in Suffield National Wildlife Area, Alberta. Canadian Field-Naturalist. 115: 345-346.

COSEWIC. 2000. Canadian species at risk. Committee On the Status of Endangered Wildlife In Canada. Ottawa.

French, A. R. 1993. Physiological ecology of the Heteromyidae: economics of energy and water utilization. Pages 509-538 in Biology of the Heteromyidae. Edited by H. H. Genoways and J. H. Brown. American Society of Mammalogists, Special Publication No. 10, Provo.

Gummer, D. L. 1995. Status of the Ord's kangaroo rat, Dipodomys ordii, in Canada. Committee On the Status of Endangered Species In Canada. Ottawa.

Gummer, D. L. 1997a. Effects of latitude and long-term isolation on the ecology of northern Ord's kangaroo rats (Dipodomys ordii). MSc. University of Calgary. Calgary.

Gummer, D. L. 1997b. Ord's Kangaroo Rat (Dipodomys ordii). Alberta Environment, Wildlife Management Division, Wildlife Status Report No. 4, Edmonton.

Gummer, D. L., and R. M. R. Barclay. 1997. Population ecology of Ord's kangaroo rats (Dipodomys ordii) in the proposed Suffield National Wildlife Area, Alberta. Prepared for the Endangered Species Recovery Fund, World Wildlife Fund Canada. Toronto.

Gummer, D. L., and K. J. Gummer. 1997. Distribution surveys for Ord's Kangaroo Rats in Alberta. Prepared for Alberta Department of Environmental Protection. Edmonton. 
Gummer, D. L., and S. E. Robertson. 2002. Evaluation of activities and survival of Ord's kangaroo rats during and post-construction of the North Suffield pipeline. Interim Project Report for EnCana Suffield Gas Pipeline Inc., Calgary.

Hall, E. R. 1981. The mammals of North America. Second edition. John Wiley and Sons, New York, 1: 1-600.

IUCN. 1994. IUCN Red List Categories. IUCN Species Survival Commission. Gland.

Kaufman, D. W. and G. A. Kaufman. 1982. Effect of moonlight on activity and microhabitat use by Ord's kangaroo rat (Dipodomys ordii). Journal of Mammalogy. 63: 309-312.

Kenny, R. J. L. 1989. Population, distribution, habitat use, and natural history of Ord's kangaroo rat (Dipodomys ordii) in the sand hill areas of southwestern Saskatchewan and southeastern Alberta. MSc. University of Manitoba. Winnipeg.

Nero, R. W. 1956. The kangaroo rat in Saskatchewan. Blue Jay. 14: 3-4.

Nero, R. W., and R. W. Fyfe. 1956. Kangaroo rat colonies found. Blue Jay. 14: 107-110.

Reynolds, H. W., and H. J. Armbruster. 1971. Field investigations of the Suffield Military Reserve: progress report. Canadian Wildlife Service. Edmonton.

Reynolds, H. W., S. J. Barry, and H. P. L. Kiliaan. 1999. Small Mammal Component Report: Canadian Forces Base Suffield National Wildlife Area, Wildlife Inventory. Canadian Wildlife Service. Edmonton.

Schmidly, D. J., K. T. Wilkins, and J. N. Derr. 1993. Biogeography. Pages 319-356 in Biology of the Heteromyidae. Edited by H. H. Genoways and J. H. Brown. American Society of Mammalogists, Special Publication No. 10, Provo.

Smith, H. C. 1972. Some recent records of Alberta mammals. Blue Jay. 30: 53-54.

Smith, H. C., and M. J. Hampson. 1969. A kangaroo rat colony in Alberta. Blue Jay. 27: 224-225. 


\section{List of Titles in This Series}

(as of January 2003)

No. 1 Alberta species at risk program and projects 2000-2001, by Alberta Sustainable Resource Development, Fish and Wildlife Division. (2001)

No. 2 Survey of the peregrine falcon (Falco peregrinus anatum) in Alberta, by R. Corrigan. (2001)

No. 3 Distribution and relative abundance of the shortjaw cisco (Coregonus zenithicus) in Alberta, by M. Steinhilber and L. Rhude. (2001)

No. 4 Survey of the bats of central and northwestern Alberta, by M.J. Vonhof and D. Hobson. (2001)

No. 52000 survey of the Trumpeter Swan (Cygnus buccinator) in Alberta, by M.L. James and A. James. (2001)

No. 6 2000/2001 Brassy Minnow inventory at Musreau Lake and outlet, by T. Ripley. (2001)

No. 7 Colonial nesting waterbird survey in the Northwest Boreal Region - 2000, by M. Hanneman and M. Heckbert. (2001)

No. 8 Burrowing owl trend block survey and monitoring - Brooks and Hanna areas, by D. Scobie and R. Russell. (2000)

No. 9 Survey of the Lake Sturgeon (Acipenser fulvescens) fishery on the South Saskatchewan River, Alberta (June-September, 2000), by L.A. Winkel. (2000)

No. 10 An evaluation of grizzly bear-human conflict in the Northwest Boreal Region of Alberta (19912000 ) and potential mitigation, by T. Augustyn. (2001)

No. 11 Harlequin duck monitoring in the Northern East Slopes of Alberta: 1998-2000 preliminary results, by J. Kneteman and A. Hubbs. (2000)

No. 12 Distribution of selected small mammals in Alberta, by L. Engley and M. Norton. (2001)

No. 13 Northern leopard frog reintroduction. Raven River - Year 2 (2000), by K. Kendell. (2001)

No. 14 Cumulative effects of watershed disturbances on fish communities in the Kakwa and Simonette watersheds. The Northern Watershed Project. Study 3 Progress report, by T. Thera and A. Wildeman. (2001)

No. 15 Harlequin duck research in Kananaskis Country in 2000, by C.M. Smith. (2001)

No. 16 Proposed monitoring plan for harlequin ducks in the Bow Region of Alberta, by C.M. Smith. (2001)

No. 17 Distribution and relative abundance of small mammals of the western plains of Alberta as determined from great horned owl pellets, by D. Schowalter. (2001)

No. 18 Western blue flag (Iris missouriensis) in Alberta: a census of naturally occurring populations for 2000 , by R. Ernst. (2000)

No. 19 Assessing chick survival of sage grouse in Canada, by C.L. Aldridge. (2000)

No. 20 Harlequin duck surveys of the Oldman River Basin in 2000, by D. Paton. (2000) 
No. 21 Proposed protocols for inventories of rare plants of the Grassland Natural Region, by C. Wallis. (2001)

No. 22 Utilization of airphoto interpretation to locate prairie rattlesnake (Crotalus viridis viridis) hibernacula in the South Saskatchewan River valley, by J. Nicholson and S. Rose. (2001)

No. 23 2000/2001 Progress report on caribou research in west central Alberta, by T. Szkorupa. (2001)

No. 24 Census of swift fox (Vulpes velox) in Canada and Northern Montana: 2000-2001, by A. Moehrenschlager and C. Moehrenschlager. (2001)

No. 25 Population estimate and habitat associations of the long-billed curlew in Alberta, by E.J. Saunders. (2001)

No. 26 Aerial reconnaissance for piping plover habitat in east-central Alberta, May 2001, by D.R.C. Prescott. (2001)

No. 27 The 2001 international piping plover census in Alberta, by D.R.C. Prescott. (2001)

No. 28 Prairie rattlesnake (Crotalus viridis viridis) monitoring in Alberta - preliminary investigations (2000), by S.L. Rose. (2001)

No. 29 A survey of short-horned lizard (Phrynosoma hernandesi hernandesi) populations in Alberta, by J. James. (2001)

No. 30 Red-sided garter snake (Thamnophis sirtalis parietalis) education and relocation project - final report, by L. Takats. (2002)

No. 31 Alberta furbearer harvest data analysis, by K.G. Poole and G. Mowat. (2001)

No. 32 Measuring wolverine distribution and abundance in Alberta, by G. Mowat. (2001)

No. 33 Woodland caribou (Rangifer tarandus caribou) habitat classification in northeastern Alberta using remote sensing, by G.A. Sanchez-Azofeifa and R. Bechtel. (2001)

No. 34 Peregrine falcon surveys and monitoring in the Parkland Region of Alberta, 2001, by R. Corrigan. (2002)

No. 35 Protocol for monitoring long-toed salamander (Ambystoma macrodactylum) populations in Alberta, by T. Pretzlaw, M. Huynh, L. Takats and L. Wilkinson. (2002)

No. 36 Long-toed salamander (Ambystoma macrodactylum) monitoring study in Alberta: summary report 1998-2001, by M. Huynh, L. Takats and L. Wilkinson. (2002)

No. 37 Mountain plover habitat and population surveys in Alberta, 2001, by C. Wershler and C. Wallis. (2002)

No. 38 A census and recommendations for management for western blue flag (Iris missouriensis) in Alberta, by R. Ernst. (2002)

No. 39 Columbian mountain amphibian surveys, 2001, by D. Paton. (2002)

No. 40 Management and recovery strategies for the Lethbridge population of the prairie rattlesnake, by $\mathrm{R}$. Ernst. (2002) 
No. 41 Western (Aechmophorus occidentalis) and eared (Podiceps nigricollis) grebes of central Alberta: inventory, survey techniques and management concerns, by S. Hanus, H. Wollis and L. Wilkinson. (2002)

No. 42 Northern leopard frog reintroduction - year 3 (2001), by K. Kendell. (2002)

No. 43 Survey protocol for the northern leopard frog, by K. Kendell. (2002)

No. 44 Alberta inventory for the northern leopard frog (2000-2001), by K. Kendell. (2002)

No. 45 Fish species at risk in the Milk and St. Mary drainages, by RL\&L Environmental Services Ltd. (2002)

No. 46 Survey of the loggerhead shrike in the southern aspen parkland region, 2000-2001, by H. Kiliaan and D.R.C. Prescott. (2002)

No. 47 Survey of native grassland butterflies in the Peace parkland region of northwestern Alberta - 2001, by M. Hervieux. (2002)

No. 48 Caribou range recovery in Alberta: 2001/02 pilot year, by T. Szkorupa. (2002)

No. 49 Peace parkland native grassland stewardship program 2001/02, by A. Baker. (2002)

No. 50 Carnivores and corridors in the Crowsnest Pass, by C. Chetkiewicz. (2002)

No. 512001 Burrowing owl trend block survey and monitoring, Brooks and Hanna areas, by D. Scobie. (2002)

No. 52 An evaluation of the ferruginous hawk population in Alberta based on recent trend data, by D.P. Stepnisky, G.L. Erickson, J. Iwaasa and B. Taylor. (2002)

No. 53 Alberta amphibian call surveys. A pilot year. Final report, by L. Takats and C. Priestley. (2002)

No. 54 Utilization of a roadside survey technique to survey burrowing owl (Athene cunicularia hypugaea) in southeastern Alberta, by J. Nicholson and C. Skiftun. (2002)

No. 55 Alberta species at risk program and projects 2001-2002, by Alberta Sustainable Resource Development, Fish and Wildlife Division. (2002)

No. 56 Developing a habitat-based population viability model for greater sage-grouse in southeastern Alberta, by C.L. Aldridge. (2001)

No. 57 Peregrine falcon surveys and monitoring in the Northeast Boreal Region of Alberta, 2001, by R. Corrigan. (2002)

No. 582002 burrowing owl trend block survey and monitoring, Brooks area, by R.F. Russell. (2002)

No. 59 Rare plant inventory of the eastern edge of the lower foothills natural subregion, west-central Alberta, by J. Doubt. (2002)

No. 60 Western (Aechmophorus occidentalis) and eared (Podiceps nigricollis) grebes of central Alberta: 2002 field summary, by S. Hanus, H. Wollis and L. Wilkinson. (2002)

No. 61 Inventory of western spiderwort (Tradescantia occidentalis) in Alberta: 2002, by S. Peters. (2003) 
No. 62 Bullsnakes (Pituophis catenifer sayi) in Alberta: literature review and data compilation, by K.J.

Kissner and J. Nicholson. (2003) 



National Library of Canada
Bibliotheque nationale du Canada

3 3286525455867 